\title{
SPONSORING, BRAND VALUE AND SOCIAL MEDIA
}

PATROCÍNIO, VALORIZAÇÃO DA MARCA E MÍDIAS SOCIAIS

PATROCINIO, VALORIZACIÓN DE LA MARCA Y MEDIOS SOCIALES

\section{ABSTRACT}

The increasing involvement of individuals in social media over the past decade has enabled firms to pursue new avenues in communication and sponsoring activities. Besides general research on either social media or sponsoring, questions regarding the consequences of a joint activity (sponsoring activities in social media) remain unexplored. Hence, the present study analyses whether the perceived image of the brand and the celebrity endorser credibility of a top sports team influence the perceived brand value of the sponsoring firm in a social media setting. Moreover, these effects are compared between existing customers and noncustomers of the sponsoring firm. Interestingly, perceived celebrity endorser credibility plays no role in forming brand value perceptions in the case of the existing customers. Implications for marketing theory and practice are derived.

KEYWORDS Social media, brand value, sponsoring, heterogeneity, celebrity endorser.

Alexander Zauner alexander.zauner@wu.ac.at

Professor at Institute for Marketing-Management, Vienna University of Economics and Business, Austria

Monika Koller monika.koller@wu.ac.at

Professor at Institute for Marketing-Management, Vienna University of Economics and Business, Austria

Matthias Fink matthias.fink@wu.ac.at

Professor for International Small Business Management and Innovation at the Leuphana University Lüneburg (Germany) and Head of the Research Institute for Liberal Professions, Vienna University of Economics and Business, Austria

Resumo 0 aumento de engajamento dos indivíduos nas mídias sociais, na última década, possibilitou as empresas explorarem novas modalidades de comunicação e projetos de patrocínio. Além de pesquisa geral quanto às mídias sociais ou ao patrocínio, as questões em relação às consequências das ações conjuntas (atividades de patrocínio nas mídias sociais) ficaram poucas exploradas. Por conseguinte, 0 presente trabalho analisa se a imagem percebida da marca e a credibilidade da celebridade endossante de uma importante equipe esportiva possa influenciar a valorização percebida da marca da empresa patrocinadora (marca de empresa) no cenário das mídias sociais. Além disso, estes resultados comparam-se entre os clientes atuais e os não clientes da empresa patrocinadora. Curiosamente, resultou-se que a credibilidade percebida da celebridade endossante quase não é um fator de construção das percepções em relação aos clientes atuais. Os nossos achados contribuem para a discussão atual na literatura sobre as vantagens do uso de mídias sociais para promover patrocínios. Palavras-Chave Mídias sociais, valorização da marca, patrocínio, heterogeneidade, celebridade endossante.

Resumen El aumento de compromiso y participación de los individuos en los medios sociales, en la última década, posibilitó que las empresas explorasen nuevas modalidades de comunicación y proyectos de patrocinio. Además de investigación general en lo que se refiere a los medios sociales o al patrocinio, las cuestiones en relación a las consecuencias de las acciones conjuntas (actividades de patrocinio en los medios sociales) permanecieron poco exploradas. El presente trabajo analiza si la imagen percibida de la marca y la credibilidad de la celebridad endosante de un importante equipo deportivo podría influenciar la valorización percibida de la marca de la empresa patrocinadora en el escenario de los medios sociales. Además, estos resultados se comparan entre los clientes actuales y los no clientes de la empresa patrocinadora. Curiosamente, resultó que la credibilidad percibida de la celebridad endosante casi no sería un factor en la construcción de las percepciones en relación a los clientes actuales. Nuestros hallazgos contribuyen a la discusión actual en la literatura sobre las ventajas del uso de medias sociales para promover patrocinios.

Palabras clave Medios sociales, valorización de la marca, patrocinio, heterogeneidad, celebridad endosante. 


\section{INTRODUCTION}

Social media platforms such as Facebook, Twitter and Google+ have advanced to such an extent that they are a highly relevant topic in our everyday private and business lives. Hence, research on social media has become multidisciplinary. Antropologists, neuroscientists, sociologists and marketers are researching in the context of this phenomenon, analysing its consequences for society in general and business initiatives in particular. The beauty of this field of research is the fact that a large part of the worldwide population is somehow connected with, or at least informed about, social media and its predominance in today's reality. 'Googling' the term 'social media' currently yields more than 3.8 billion hits, the term 'social media marketing' more than 1.5 billion. A lot of information on social media is available online. The emergence of the topic has opened up a wide variety of research questions to be resolved, including the need to gain a more detailed understanding of the phenomenon itself. For instance, the extent to which individuals engage in social networks varies considerably, due to manifold reasons. Very recently, Kanai and others (2011) published a study addressing this variability in individuals' social web participation based on neuroscientific data. They report that quantitative variation in the number of friends an individual declares on a social network site predicted grey matter density in the right superior temporal sulcus, left middle temporal gyrus and entorhinal cortex (KANAI and others, 2011). These results suggest the size of an individual's online social network to be closely linked to focal brain structures implicated in social cognition (KANAI and others, 2011).

Hence, the increasing involvement of individuals in social media has important implications for multiple scientific disciplines. The natural sciences are predominantly interested in searching for biological mechanisms associated with human online behaviour whereas the social sciences in general and business as well as marketing research in particular are more interested in the implications such individual online behaviour might impose for managers and policy makers. For instance, it is vital to further analyse the potential social media has for business and entrepreneurial applications. In January 2012, Facebook reports that it already has more than 800 million active users worldwide (www.facebook.com, 2012).
Regarding its professional potential, in the second half of 2011, about 2.5 million websites integrated with Facebook, including over 80 of comScore's top 100 US websites and over half of its top 100 global websites (www.facebook.com, 2011). These numbers underline the importance of Facebook as a communication tool for both end users and firms. For entrepreneurs, social media platforms can be used as a vehicle for communicating with their targeted customer groups (ANKENY, 2011a; FORBES, 2011). The literature reports that up to 60 percent of the Facebook advertising market is made up of small and mid-sized businesses (ANKENY, 2011b). Hence, integrating web 2.0 applications such as social media platforms into a company's set of communication channels may lead to multiplicative benefits (BUGHIN and CHUI, 2011).

The internet has altered the way consumers interact with products and brands (EDELMAN, 2010). For instance, specific brand community sites have advanced to the stage where they are widely used by companies to encourage consumers to interact with their products and brands (for an overview on brand communities, see e.g, COVA and WHITE, 2010). However, the internet has changed and will continue to change (CAMPBELL and others, 2011). Hence, a company is well-advised to thoroughly monitor the time and money it invests in social media activity. A lot of businesses still do not have enough comprehensive information about the pros and cons of, for example, adopting Facebook as an extra communication channel (ANKENY, 2011b). Fischer and Reuber (2011) note that there is still a lack of knowledge of what can actually be done with social media by entrepreneurs. Moreover, there is virtually no certainty about which activities might be effective. Although a rapidly expanding body of scholarly work and practitioner literature on social media and business practices does exist (FISCHER and REUBER, 2011), there are still blind spots in terms of the underlying marketing mechanisms in social media and other forms of communication, such as sponsoring. For instance, if a company decides to engage with Facebook, it can either create its own Facebook page, run under the company's name, or collaborate with a partner and run an independent page on which both partners appear jointly. A sponsoring company engaging with the Facebook fansite of a celebrity sports team that it is sponsoring would be a perfect example of such a joint activity. In this case, social media might help to boost how the company brand is perceived 
by consumers. A recently published analysis of performance data on 50 top US-based corporations indicates that the corporations that consistently invest in sponsorship outperform market averages (JENSEN and HSU, 2011). Hence, integrating sports sponsorship and marketing activities via specific fan groups on social media platforms might have several positive effects for a company. This could be advantageous, especially regarding the company's brand image and the perceived brand value.

As far as we are aware, there is still little known about the mechanisms of sports sponsorship and perceived brand value within social media. We attempt to close this gap in the previous research by answering the following two questions:

(1) Do perceived brand image and/or the celebrity endorser credibility of a sports team that runs a Facebook fan site positively affect the perceived brand value of the sponsoring firm?

(2) Do these effects differ on the existing customers and non-customers of the sponsoring firm?

We collected data from 322 members of the company-sponsored Facebook fan site of a celebrity sports team (a volleyball team). In our case, the sponsoring firm was one of Europe's largest mobile telecommunication service providers. In the present paper, we empirically investigate the contributions of brand image and the celebrity endorser credibility of the sports team on the brand value perceived by the Facebook group members. We further test the moderating effect of being an existing customer versus a non-customer of the service provider (sponsoring firm). Based on the findings, we derive ample managerial implications and highlight directions for further research.

\section{THEORETICAL FRAMEWORK}

\section{Perceived value}

The focal construct in our study is the concept of perceived value. Since consumers attempt to maximize value in their market exchanges, 'customer value' is of fundamental interest for both managers and scholars (BHARADWAJ and FLOH, 2008). Hence, it has been called one of the most powerful forces in today's marketplace (PATTERSON and SPRENG,
1997) and an underlying source of competitive advantage (WOODRUFF, 1997). It is defined as a customer's perceived preference for and evaluation of those product attributes, attribute performances, and consequences arising from use, that facilitate the achievement of the customer's goals in usage situations (WOODRUFF, 1997). The recognition of the importance of the customer value concept as a major antecedent to intentional post-consumption concepts (e.g, loyalty), as well as to actual behaviour, has generated a plethora of research (see, e.g, KOLLER, FLOH, ZAUNER, 2011). Yet, empirical research on customer value is still fragmented and inconclusive (SANCHEZFERNANDEZ, INIESTA-BONILLO, HOLBROOK, 2009), especially regarding the link between perceived value and brand perceptions. For example, Parasuraman (1997) emphasizes the potential relevance of brand perceptions as sources of value from the consumer perspective. In doing so, he identifies the need for sound and empirical research on this topic.

\section{Perceived brand value}

Customer value as a general concept can be discussed from both a supply and a demand perspective. From a supply perspective, for example, there is a strong stream of research on customer lifetime value or customer equity (MAAS and GRAF, 2008). From a demand persepctive, perceived customer value stands for the multidimensional value facets (functional, economic, emotional and social) perceived by an individual consuming the product or service (see, e.g, SWEENEY and SOUTAR, 2001). In the present paper, we explicitly focus on the latter, perceived value from the consumer's perspective. However, we do not focus on the general concept of perceived customer value related to a product or service. We rather address perceived brand value from a customer perspective. This concept can be seen as a particular type of perceived customer value.

Perceived brand value can be defined as value facets (functional, economic, emotional and social) perceived by an individual consuming a particular brand. From a more general perspective, akin to customer value, brand value can as well be defined from a supply perspective. From a supply perspective, brand value is seen as the value of a product and/or company brand in terms of a company's asset. Hence, brand value may enter into the sales and the purchase price of a company (GABAY and others, 2009). 
In contrast, for the purpose of this paper, from a demand (consumer) perspective, perceived brand value means the multidimensional value facets a consumer derives from a product and/or company brand. In other words, a brand delivers a certain set of values that determine its brand personality and distinguish it from other brands, which in turn imparts some perceived utility on the customer (CHRISTOPHER, 1996). Whereas, in the history of research on value, it used to be conceptualized as a unidimensional construct (e.g, utility in terms of functional value only) (e.g, BOLTON and DREW, 1991; SINHA and DESARBO, 1998), recent research has turned to a multidimensional conceptualization of value (e.g, KOLLER, FLOH, ZAUNER, 2011; SANCHEZFERNANDEZ, INIESTA-BONILLO, HOLBROOK, 2009; SWEENEY and SOUTAR, 2001). Following this trend, we adopt a multidimensional (functional, economic, emotional and social) perspective of perceived brand value in the present research. Hence, in our empirical study, the construct of the perceived brand value of the sponsoring firm comprises multiple value facets.

\section{Perceived brand image and perceived brand value}

Aaker (1991) defines brand image as a set of associations, usually grouped in some meaningful way. Comparably, Keller (1998) characterizes the concept as "perceptions about a brand as reflected by the brand associations held in consumers' memory". A brand's image combines cognitive and affective brand beliefs, which together form the consumer's overall impression of the brand (BRODIE, WHITTOME, BRUSH, 2009). In other words, brand image is a multidimensional construct consisting of various brand associations which firms transfer from the brand to the consumer's memory through integrated marketing communication channels, such as social media (SMITH, 2004). Although research on the influence of customers' brand perceptions on perceived brand value is scarce, both conceptual and empirical evidence exists indicating a substantial, positive relationship. For example, Erdem and Swait (1998) demonstrate through signalling theory that a brand's personality positively affects perceived service quality and value. Of particular relevance to this study is the research by Brodie, Whittome and Brush (2009), which shows a significant positive effect of brand image on customer value. According to these authors, all aspects of the brand (brand image, company image, employee trust and company trust) have a positive influence on value perceptions.

\section{Celebrity endorser credibility and perceived brand value}

Ohanian (1990) developed the celebrity endorser credibility scale, which informs and reflects the dimensions of source valence. This scale comprises three dimensions: trustworthiness, expertise and attractiveness. Combined, these three dimensions describe a communicator's characteristics that influence a receiver's acceptance of a message. Trustworthiness "refers to the consumer's confidence in the source for providing information in an objective and honest manner" (OHANIAN, 1991). Expertise is defined as "the extent to which a communicator is perceived to be a source of valid assertions" (HOVLAND, JANIS, KELLEY, 1953). Finally, attractiveness refers to the physical attractiveness of the source to the respondent and the consequent influence on message receptivity.

Firms invest large sums of money to align their market offerings with celebrity endorsers (AGRAWAL and KAMAKURA, 1995). A celebrity endorser can be defined as "any individual who enjoys public recognition and who uses this recognition on behalf of a consumer good by appearing with it in an advertisement" (MCCRACKEN, 1989). In this way, it is hoped that specific characteristics or qualities (e.g, expertise) of celebrities will be transferred to products via marketing communications (ERDOGAN, 1999). Although the effectiveness of a celebrity endorser is dynamic, and dependent on the celebrity, the market offering and societal conditions (e.g, time and place) (SILVERA and AUSTAD, 2004), extant research clearly documents that celebrity endorsers have positive effects on product evaluations (e.g, DEAN and BISWAS, 2001), attitudes (e.g, KAHLE and HOMER, 1985; KAMINS, 1989) and behavioural intentions (e.g, LIU, HUANG, MINGHUA, 2007). However, the relationship with perceived brand value remains disregarded. This is surprising, considering that the customer value concept is of paramount importance in current marketing research (see, e.g, KATSIKEAS, ROBSON, HULBERT, 2001).

\section{CONCEPTUAL MODEL AND HYPOTHESES}

The theoretical framework discussed suggests that the following conceptual model (see Figure 
1) and hypotheses should be empirically tested. We formulate two core hypotheses regarding the impact of perceived brand image and perceived celebrity endorser credibility on how the members of a Facebook fan group assess the perceived brand value of the sponsoring company ( $\mathrm{H} 1$ and $\mathrm{H} 2$ ). Not all members of the Facebook fan group being investigated are necessarily already customers of the sponsoring company. Existing customers will be more committed to the brand in general. This assumption is based on previous literature on general customer loyalty, brand love and brand loyalty (e.g, BATRA and others, 2012). They are already in a commercial relationship with the telecommunication service provider (sponsoring firm). In our particular case, they even make the effort to engage in a social media platform of a celebrity sports team that is sponsored by the service provider. Based on the theoretical reasoning underlying the phenomenon of brand attachment (PARK and others, 2010), this active involvement leads to the assumption, that these existing customers have already formed emotional ties with the company and the brand. Hence, it can be assumed that there are two sub-groups, depending on whether or not the member is already a customer of the sponsoring company (H3). Within this assumption of heterogeneity articulated in $\mathrm{H} 3$, we further assume that existing customers score higher on perceived brand image, celebrity endorser credibility and perceived brand image. Moreover, the explanatory power of perceived brand image and celebrity endorser credibility on perceived brand value is also expected to be more pronounced among existing customers than among non-customers of the sponsoring firm.

H1: Perceived brand image has a positive effect on the perceived brand value of the sponsoring firm in the context of social media.

$\mathrm{H} 2$ : The perceived celebrity endorser credibility of the sponsored sports team has a positive effect on the perceived brand value of the sponsoring firm in the context of social media.

H3: The effects of perceived brand image and perceived celebrity endorser credibility on the perceived brand value of the sponsoring firm in the context of social media are influenced by whether or not the fan group member is already a customer of the sponsoring firm.

\section{METHODOLOGY}

\section{Data collection and sample description}

Data collection was administered through an online questionnaire, sent via the Facebook website of an Austrian celebrity volleyball team. The two members of the team always appear in public together. Thus, their fans attribute characteristics to the team and not to the individuals. This makes the team an adequate unit of analysis. An electronic invitation to take part in the research project was emailed to 1,286 Facebook 'friends' of the celebrity sports team. In the ten days

\section{Figure 1 - Conceptual model}

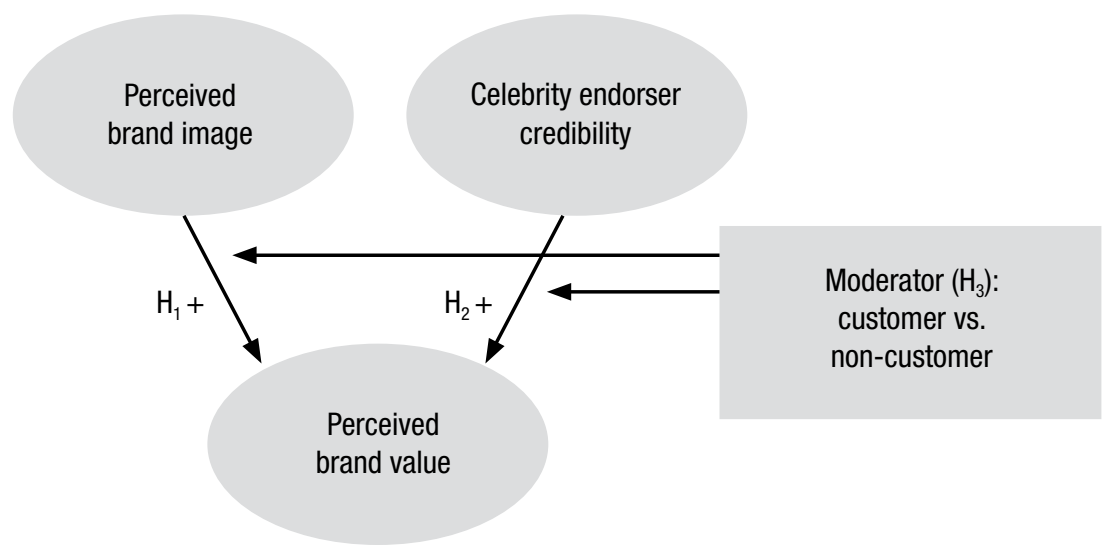


during which the survey was run, 322 group members participated, yielding a response rate of $25 \%$. Regarding the final sample, $31 \%$ of our respondents are female and $69 \%$ male. The over-representation of males can be explained by the context of the study. Men tend to be more interested in sports. Further, 38\% ( $n=121)$ were already customers of the sponsoring firm, and 62\% ( $n=201)$ were non-customers. However, the non-customers did have contracts with other service providers. The gender distribution is fairly similar in both sub-samples: customers (32\% female, $68 \%$ male) and non-customers (31\% female, 69\% male).

\section{Measures}

As previously described, we focus on the respective relationships of perceived brand image and celebrity endorser credibility with perceived brand value. Celebrity endorser credibility was measured following Ohanian (1990). A reduced scale was employed which was adapted to the requirements of the study and comprised three items (one for each dimension of source credibility). We measured brand image based on scales previously used in scientific research (CHAUDHURI and HOLBROOK, 2001; MARTINEZ SALINAS and PINA PEREZ, 2009; YOO, DONTHU, LEE, 2000). Martínez Salinas and Pina Perez (2009), for example, use similar measures to assess the effects of brand extensions on brand image. Based on Sweeney and Soutar (2001), we conceptualized perceived value as a multidimensional concept, comprising both cognitive and affective factors. We measured all latent constructs using multiple-item scales derived from already existing scales. The wording of the items was slightly adapted to the current application. Each construct was measured using at least three items, as recommended by Anderson and Gerbing (1988). The items measuring perceived brand image and perceived brand value were presented with a 7-point rating scale, with endpoints verbalized as $1=$ 'fully disagree' and $7=$ 'fully agree'. Celebrity endorser credibility was measured with a 7-point semantic differential scale.

A series of statistical tests was conducted to test construct validity (see Table 3). Factor analysis was used to determine whether the items could be reduced to the latent constructs under scrutiny. All factor loadings were highly significant $(\mathrm{p}<0.001)$ and exceeded the suggested threshold of 0.5 , demonstrating a high level of convergent validity (DUNN, SEAKER, WALLER, 1994). The results for discriminant validity, composite reliability, AVE and Cronbach's alpha were also highly satisfactory, meeting the particular requirements suggested in literature (FORNELL and LARCKER, 1981).

\section{EMPIRICAL RESULTS}

To empirically test the hypotheses in our conceptual model, we employed stepwise linear regression analysis. Perceived brand value was modelled as the dependent variable. Perceived brand image and celebrity endorser credibility were used as the independent variables. We ran two separate models, one for each sub-group, to test $\mathrm{H} 1$ and H2. The results are shown in Table 1.

\section{Table 1 - Test of hypotheses}

\begin{tabular}{|c|c|c|c|c|c|}
\hline \multicolumn{6}{|c|}{ Customers $(n=121)$} \\
\hline Model & & & $\beta$ & S.E. & sig. \\
\hline & Brand image & & 0.730 & 0.076 & $0.000^{\star \star *}$ \\
\hline & Celebrity endorser credibility & & 0.032 & 0.138 & 0.618 \\
\hline & Adjusted $\mathrm{R}^{2}$ & 0.56 & & & \\
\hline \multicolumn{6}{|c|}{ Non-Customers ( $n=201)$} \\
\hline \multirow[t]{4}{*}{ Model } & & & $\beta$ & S.E. & sig. \\
\hline & Brand image & & 0.719 & 0.045 & $0.000^{\star \star \star}$ \\
\hline & Celebrity endorser credibility & & 0.169 & 0.084 & $0.000^{\star \star \star}$ \\
\hline & Adjusted $R^{2}$ & 0.53 & & & \\
\hline
\end{tabular}

Standardized regression coefficients are displayed in Table $1\left(^{\star \star \star} p<0.001\right)$ 
In $\mathrm{H} 1$ and $\mathrm{H} 2$, we proposed that perceived brand image and perceived celebrity endorser credibility would have a positive impact on perceived brand value. The results show that $\mathrm{H} 1$ and $\mathrm{H} 2$ can both be accepted for non-customers. However, among existing customers, only brand image turned out to enhance perceived brand value. Celebrity endorser credibility turned out to be non-significant. Hence, for the sub-sample of existing customers, only $\mathrm{H} 1$ could be accepted, while $\mathrm{H} 2$ had to be declined. These results affirm $\mathrm{H} 3$ as well, which proposed that the circumstance of being a customer versus a non-customer would serve as a moderator for the proposed relationships.

As a second step, we compared the mean levels of the central constructs of our model for the two subgroups. Table 2 shows the results of these comparisons.
As expected, perceived brand image and perceived brand value are both significantly more pronounced for the existing customers of the sponsoring firm than for the non-customers. These results reflect the customers' commitment to their current mobile service provider and are in line with our assumptions derived from previous literature. Interestingly, no significant difference was found between customers and noncustomers for perceived celebrity endorser credibility. Both sub-groups rated the perceived celebrity endorser credibility of the celebrity sports team equally highly. A possible explanation for this finding could lie in the mere fact that both groups actually like the sports team; otherwise they would not have joined the fan site in the first place. Hence, the proposed assumptions articulated in $\mathrm{H} 3$ are only partly supported by the data.

\section{Table 2 - Descriptives of focal constructs (means and standard deviations)}

\begin{tabular}{|l|c|c|c|c|}
\hline \multirow{2}{*}{} & \multicolumn{2}{|c|}{ Customers (n=121) } & \multicolumn{3}{|c|}{ Non-Customers (n=201) } \\
\hline (1) Brand image & Mean & SD & \multicolumn{2}{|c|}{ Mean } \\
\hline (2) Celebrity endorser credibility & $5.82^{\star \star \star}$ & 1.07 & 4.82 & 1.21 \\
\hline$(3)$ Perceived brand value & 6.35 & 0.61 & 6.26 & 0.64 \\
\hline
\end{tabular}

Note: ${ }^{* \star} p<0.001$ (t-test for independent samples)

\section{Table 3 - Measurement model and questionnaire items}

\begin{tabular}{|c|c|c|c|c|}
\hline Variables & Items in the questionnaire & $\mathbf{F L}$ & AVE & CR \\
\hline \multirow{5}{*}{$\begin{array}{l}\text { Brand image (Cronbach's Alpha } \\
=0.80)\end{array}$} & It's one of the best brands in the sector & 0.786 & 0.64 & 0.90 \\
\hline & The brand is well established in the market & 0.877 & & \\
\hline & I can recognize ... among competing brands & 0.787 & & \\
\hline & I can quickly recall the symbol or logo of .... & 0.750 & & \\
\hline & $\ldots$ is an honest brand & 0.800 & & \\
\hline \multirow{3}{*}{$\begin{array}{l}\text { Celebrity endorser credibility } \\
\text { (Cronbach's Alpha }=0.86 \text { ) }\end{array}$} & insincere/sincere & 0.822 & 0.70 & 0.88 \\
\hline & out/in & 0.825 & & \\
\hline & not exemplary/exemplary & 0.868 & & \\
\hline \multirow{4}{*}{$\begin{array}{l}\text { Perceived brand value } \\
\text { (Cronbach's Alpha }=0.85 \text { ) }\end{array}$} & ... has high quality, compared to the competitors & 0.868 & 0.69 & 0.90 \\
\hline & ....is one that I would enjoy & 0.853 & & \\
\hline & ...offers value for money & 0.818 & & \\
\hline & ...has a positive reputation & 0.781 & & \\
\hline
\end{tabular}

Note: $F L=$ factor loading; $A V E=$ average variance extracted; $C R=$ composite reliability 
Taking the results of the two regression analyses and the descriptive comparison of the mean levels of the focal constructs (see Table 2) together, brand image turned out to significantly influence perceived brand value, regardless of whether or not the group member was already a customer of the sponsoring firm. Interestingly, celebrity endorser credibility was only relevant for forming brand value perceptions in the case of the non-customers. For the existing customers, it turned out to be irrelevant. As reported in Table 2, both sub-groups rated the perceived celebrity endorser credibility of the celebrity sports team equally highly. However, regarding its explanatory value regarding perceived brand value, celebrity endorser credibility is only relevant in the case of non-customers. Although, with a standardised beta-coefficient of 0.169 , to a moderate extent only. These results suggest two main implications for theory and practice, which are discussed in the concluding section of the paper.

\section{CONCLUSION, IMPLICATIONS AND FURTHER RESEARCH}

Confronted with exchangeable market offerings and similar communication patterns, firms have to break with past solutions and exploit new approaches in order to provide additional value to customers. In view of this, this research addresses the issue of how perceived brand value can be enhanced in a social media context. We analyse whether the perceived image of the company brand and the celebrity endorser credibility of the sports team in question positively influence the perceived brand value of the sponsoring firm. The results significantly broaden the theoretical knowledge on perceived brand value and its antecedents in a social media context. The results of our study confirm a significant influence of perceived brand image on the perceived brand value of the sponsoring firm for existing customers as well as for non-customers. However, the mean levels of perceived brand image and perceived brand value turned out to be significantly higher for existing customers than for non-customers. This turned out to be in line with our assumptions derived from literature: existing customers are already more committed and attached to their service provider. Moreover, for the non-customers, as well as perceived brand image, celebrity endorser credibility also turned out to have a significant, albeit only moderate, impact on perceived brand value. These results open up theoretical and managerial implications. Two major implications bridging the gap between the present study and the larger literature are discussed in the following.

First, the study confirms a proposed moderating effect, depending on whether or not the fan group member is already a customer of the sponsoring company. This contributes also to a larger theoretical picture, as knowledge on heterogeneity among consumers in this particular context has been scarce. A possible theoretical explanation for the non-significant path between celebrity endorser credibility and perceived brand value in case of existing customers could lie in the fact that existing customers have already developed strong brand value perceptions, regardless of any celebrity endorser credibility evaluations.

However, even though it is highly significant, the influence of celebrity endorser credibility is also not very strong among non-customer. This implies the second main conclusion that can be drawn. When people join the fan site of a celebrity sports team that a particular company is sponsoring, the perceived credibility of this sports team plays a minor role for forming brand value perceptions. This finding contributes to the larger literature on the role of testimonials and celebrity endorsers. The role of celebrity endorser credibility in social media seems to follow its very specific rules, which need closer attention in further research. Moreover, the present findings suggest that it is especially vital to research the underlying psychological mechanisms which might explain the varying role of celebrity endorser credibility in forming perceived brand value in a social media context.

At the same time, this study is also of value from a managerial perspective. If the target for a sponsoring company engaging in a joint Facebook fansite is to boost perceived brand value among the current customers and non-customers, the first step is to keep the perceived brand image high, as this variable turned out to strongly impact perceived brand value in both groups. However, if a firm wants to leverage perceived brand value among non-customers, it is advised to keep also celebrity endorser credibility high. It would be well-advised to choose its sports team (or celebrity) carefully. As the positive relation between perceived (brand) value and behavioural (purchase or loyalty) intentions has already been well established, investing in celebrity endorser credibility may even turn non-customers into potential future customers. In 
that case, the social media activities of the sponsoring firm could indirectly translate into enhanced business performance.

To sum up, the results of the present study indicate that marketing activities via social media (e.g, Facebook) have a positive effect on customers' value perceptions of the sponsoring firm. Customers who perceive that they receive superior value tend to become more committed to the organization and recommend others in their reference group to become loyal to the same organization. Perceived brand value can be positively influenced by encouraging interactions with groups of like-minded members on Facebook, and identification with the group in a social context; such groups can be offered by a firm and/or a brand, but primarily run by the consumers themselves. As there is a lively communication among the members of social media networks such as Facebook fan groups, the active members can become agents for the marketer by actively spreading its message within the group and also to new members. By identifying and targeting these active users, firms can leverage the impact of their marketing activities and enhance the cost-effectiveness of such activities within the social media network. In fact, these communication agents might become cocreators of the perceived brand value within the group, yet under certain circumstances, their multiplying effect might also turn against the firm.

The same applies to the celebrities who are used to catch the attention of the customers and motivate them to join the social media network. The selection of celebrities turns out to be crucial since their credibility is, at least to a moderate extent, relevant to the noncustomers. If a company wants to turn these noncustomers into potential future customers, celebrity endorser credibility is a focal construct that should be studied in more detail. This is especially the case as the marketing literature also points out the potential risks of celebrity endorsements. The effectiveness of celebrity endorsers is, for example, dependent on factors such as their attractiveness and credibility, the product type, the message and the customer's level of involvement (ERDOGAN, 1999).

Despite the strength of this research, it does have some limitations. Our survey only captures the respondents' views at one point in time. This does not allow us to empirically investigate the proposed direction of causality. As long as we do not have longitudinal data at hand, we can only argue about which variable is a cause and which is an effect based on theoretical considerations. Moreover, because we administered data collection using a survey tool embedded in Facebook, the conciseness of the questionnaire was of high priority. Thus, we used reduced measurement scales and focused on the most important control variables only. However, some other characteristics of the context and of the interviewees could have a systematic influence on the relationships surveyed. This provides an attractive starting point for further research. Future studies should test our results in terms of their sensitivity to the survey instrument and additional contextual factors. For instance, qualitative methods could help to uncover the objective structure of reasoning behind the online discussion within social media communities. Moreover, future research should also collect data in an offline setting, comparing Facebook fangroup members with fans of the celebrity sports team not engaging in social media. This approach could help to filter out the effect of the social medium itself, more comprehensively. In the present study, perceived brand value was modelled as a dependent variable being predicted by perceived brand image and perceived celebrity endorser credibility. The literature suggests that perceived value has a considerable impact on behavioural intentions, such as purchase, loyalty or word-of-mouth (PARASURAMAN and GREWAL, 2000). In view of this, future research should also incorporate loyalty or other purchase-related variables in an advanced model in which perceived brand value would serve as a mediator between perceived brand image, celebrity endorser credibility and, for instance, wordof-mouth or loyalty intentions towards the sponsoring firm. Doing so would enable us to infer managerial implications directly related to boosting economic performance.

\section{REFERENCES}

AAKER, D. A. Managing brand equity: capitalizing on the value of a brand name. New York: Free Press, 1991.

AGRAWAL, J; KAMAKURA, W. The economic worth of celebrity endorsers: an event study analysis. Journal of Marketing, v. 59, n.3, p. 56-62, 1995.

ANDERSON, J. C; GERBING, D.W. Structural equation modeling in practice: a review and recommended two-step approach. Psychological Bulletin, v. 103, n. 3, p.411-423, 1988. 
ANKENY, J. Facebook on fire. Entrepreneur, August, p. 44-45, 2011a.

ANKENY, J. Facelift. Entrepreneur, June, p. 56-59, 2011b.

BHARADWAJ, S; FLOH, A. Linking brand and customer attitudinal and behavioral metrics to financial outcomes: a latent growth modeling approach. In: PROCEEDINGS OF THE 30TH INFORMS MARKETING SCIENCE CONFERENCE, 2008, Vancouver.

BATRA, R; AHUVIA, A; BAGOZZI, R. P. Brand Love. Journal of Marketing, v. 76, n. 2, p. 1-16, 2012.

BOLTON, R. N; DREW, J. H. A multistage model of customers' assessments of service quality and value. Journal of Consumer Research, v. 17, n. 4, p. 375-384, 1991.

BROdie, R. J; WhitTome, J. R. M; BRUsh, G. J. Investigating the service brand: a customer value perspective. Journal of Business Research, v. 62, n. 3, p. 345-355, 2009.

BUGHIN, J; CHUI, M. How web 2.0 pays off: the growth dividend enjoyed by networked enterprises. McKinsey Quarterly, v. 2, p. 17-21, 2011.

CAMPBELL, C; PITT, L. F; PARENT, M; BERTHON, P. R. Understanding consumer conversations around ads in a web 2.0 world. Journal of Advertising, v. 40, n. 1, p. 87102, 2011.

CHAUDHURI, A; HOLBROOK, M. B. The chain of effects from brand trust and brand affect to brand performance: the role of brand loyalty. Journal of Marketing, v. 65, n. 2, p. 81-93, 2001.

CHRISTOPHER, M. From brand values to customer value. Journal of Marketing Practice: applied marketing science, v. 2, n. 1, p. 55-66, 1996.

COVA, B; WHITE, T. Counter-brand and later-brand communities: the impact of web 2.0 on tribal marketing approaches. Journal of Marketing Management, v. 26, n. 3-4, p. 256-270, 2010.

DEAN, D. H; BISWAS, A. Third-party organization endorsement of products: an advertising cue affecting consumer prepurchase evaluation of goods and services. Journal of Advertising, v. 30, n. 4, p. 41-57, 2001.
DUNN, S. C; SEAKER, R.F; WALLER, M.A. Latent variables in business logistics research: scale development and validation. Journal of Business Logistics, v. 15, n. 2, p.145172, 1994.

EDELMAN, D. C. Branding in the digital age: you're spending your money in all the wrong places. Harvard Business Review, v. 88, n. 12, p. 62-69, 2010.

ERDEM, T; SWAIT, J. Brand equity as a signaling phenomenon. Journal of Consumer Psychology, v. 7, n. 2, p. 131-157, 1998.

ERDOGAN, B. Z. Celebrity endorsement: a literature review. Journal of Marketing Management, v. 15, n. 4, p. 291-314, 1999.

FACEBOOK. www.facebook.com, 2012.

FACEBOOK. www.facebook.com, 2011.

FISCHER, E; REUBER, A. R. Social interaction via new social media: (How) can interactions on Twitter affect effectual thinking and behavior. Journal of Business Venturing, v. 26, p. 1-18, 2011.

FORBES. Our startup summit with Michael Dell. Forbes, August 22, p. 80-86, 2011.

FORNELL, C; LARCKER, D. F. Structural equation models with unobservable variables and measurement error. Journal of Marketing Research, v. 18, n. 1, p.39-50, 1981.

GABAY, G; MOSKOWITZ, H. R; BECKLEY, J; ASHMAN, H. Consumer centered "brand value" of foods: drivers and segmentation. Journal of Product and Brand Management, v. 18, n. 1, p. 4-16, 2009.

HOVLAND, C. I; JANIS, I. L; KELLEY, H. H. Communication and persuasion. New Haven, CT: Yale University Press, 1953.

JENSEN, J. A; HSU, A. Does sponsorship pay off? An examination of the relationship between investment in sponsorship and business performance. International Journal of Sports Marketing and Sponsorship, v. 12, n. 4, 2011.

KAHLE, L. R; HOMER, P. M. Physical attractiveness of the celebrity endorser: a social adaptation perspective. Journal 
of Consumer Research, v. 11, n. 4, p. 954-961, 1985.

KAMINS, M. A. Celebrity and noncelebrity advertising in a two-sided context. Journal of Advertising Research, v. 29, n. 3, p. 34-42, 1989.

KANAI, R; BAHRAMI, B; ROYLANCE, R; REES, G. Online social network size is reflected in human brain structure. Proceedings of the Royal Society B, doi:10.1098/ rspb.2011.1959, p. 1-8, 2011.

KATSIKEAS, C. S; ROBSON, M. J; HULBERT, J. M. In search of relevance and rigour for research in marketing. Marketing Intelligence \& Planning, v. 22, n. 5, p. 568-578, 2001.

KELLER, K. L. Strategic brand management: building, measuring, and managing brand equity. Upper Saddle River, NJ: Prentice-Hall, 1998.

KOLLER, M; FLOH, A; ZAUNER, A. Further insights into perceived value and consumer loyalty: a "green" perspective. Psychology \& Marketing, v. 28, n. 12, p. 11541176, 2011.

LIU, M. T; HUANG, Y.-Y; MINGHUA, J. Relations among attractiveness of endorsers, match-up, and purchase intention in sport marketing in China. Journal of Consumer Marketing, v. 24, n. 6, p. 358-365, 2007.

MAAS, P; GRAF, A. Customer value analysis in financial services. Journal of Financial Services Marketing, v. 13, n. 2, p. 107-120, 2008

MARTINEZ SALINAS, E; PINA PEREZ, J. M. Modeling the brand extensions' influence on brand image. Journal of Business Research, v. 62, n. 1, p. 50-60, 2009.

MCCRACKEN, G. Who is the celebrity endorser? Cultural foundations of the endorsement process. Journal of Consumer Research, v. 16, n. 3, p. 310-321, 1989.

OHANIAN, R. Construction and validation of a scale to measure celebrity endorsers' perceived expertise, trustworthiness, and attractiveness. Journal of Advertising, v. 19, n. 3, p. 39-52, 1990.

OHANIAN, R. The impact of celebrity spokespersons' perceived image on consumers' intention to purchase. Journal of Advertising Research, v. 31, n. 1, p. 46-54, 1991.
PARASURAMAN, A. Reflections on gaining competitive advantage through customer value. Journal of the Academy of Marketing Science, v. 25, n. 2, p. 15, 1997.

PARASURAMAN, A; GREWAL, D. The impact of technology on the quality-value-loyalty chain: a research agenda. Journal Academy of Marketing Science, v. 28, n. 1, p. 168-174, 2000.

PARK, C. W; MACINNIS, D. J; PRIESTER, J; EISINGERICH, A. B; IACOBUCCI, D. Brand attachment and brand attitude strength: conceptual and empirical differentiation of two critical brand equity drivers. Journal of Marketing, v. 74, n. 6, p. 1-17, 2010.

PATTERSON, P. G; SPRENG, R. A. Modelling the relationship between perceived value, satisfaction and repurchase intentions in a business-to-business, services context: an empirical examination. International Journal of Service Industry Management, v. 8, n. 5, p. 414-434, 1997.

SANCHEZ-FERNANDEZ, R; INIESTA-BONILLO, M. Ã; HOLBROOK, M. B. The conceptualisation and measurement of consumer value in services. International Journal of Market Research, v. 51, n. 1, p. 93-113, 2009.

SILVERA, D. H; AUSTAD, B. Factors predicting the effectiveness of celebrity endorsement advertisements. European Journal of Marketing, v. 38, n. 11/12, p. 15091526, 2004.

SINHA, I; DESARBO, W. S. An integrated approach toward the spatial modeling of perceived customer value. Journal of Marketing Research, v. 35, n. 2, p. 236-249, 1998.

SMITH, G. Brand image transfer through sponsorship: a consumer learning perspective. Journal of Marketing Management, v. 20, n. 3/4, p. 457-474, 2004.

SWEENEY, J. C; SOUTAR, G. N. Consumer perceived value: the development of a multiple item scale. Journal of Retailing, v. 77, n. 2, p. 203-220, 2001.

WOODRUFF, R. B. Customer value: the next source for competitive advantage. Journal of the Academy of Marketing Science, v. 25, n. 2, p. 139-153, 1997.

YOO, B; DONTHU, N; LEE, S. An examination of selected marketing mix elements and brand equity. Journal of the Academy of Marketing Science, v. 28, n. 2, p. 195-211, 2000. 